\title{
EXCHANGE RATE, FISCAL POLICY AND INTERNATIONAL OIL PRICES IMPACT ON OIL PRICES IN PAKISTAN: A VOLATILITY AND GRANGER CAUSALITY ANALYSIS.
}

\section{Saqib Anwar Saddiqui, Muhammad Jawad, Munazza Naz, Ghulam Shabbir Khan Niazi}

(1) Department of Leadership and Management Studies, National Defence University , Islamabad, Pakistan

(2) Department of Economics, University of York, York, United Kingdom

(3) Department of Economics, University of York, York, United Kingdom (4) Department of Leadership and Management Studies, National Defence University, Islamabad, Pakistan

Muhammad Jawad Department of Economics, University of York, York, United Kingdom muhammad_jawad85@yahoo.com

Article info

Paper category: Original Scientific Paper Received: 18.12.2017. Accepted: 6.3.2018. JEL classification: $\mathrm{G}_{21}, \mathrm{E}_{44}, \mathrm{C}_{1} 3, \mathrm{C}_{22}, \mathrm{E}_{51}$

Keywords Exchange Rate; Fiscal Policy; Oil Price; Volatility 


\begin{abstract}
Purpose. Crude oil is an important and most demanded commodity throughout the world. There are various oil processes like electricity production, manufacturing processes and transport sector. Oil is the basic necessity thus is important to study the volatility in oil prices because oil price volatility reduces the aggregate output for short run and as a result uncertainty increases and investment also decreases (Guo and Kliesen, 2005). This research analysis the effect of exchange rate variation and the fiscal policy changes on the oil price volatility and granger causality of macroeconomic variables. Lee (1998) defined volatility as the standard deviation in a given period. She submitted that Volatility has a negative and significant impact on economic growth immediately, while the impact of oil price changes delays until after a year. She concludes by stating that it is volatility/change in crude oil prices rather than oil price level that has a significant influence on economic growth.
\end{abstract}

Methodology. GARCH $(1,1)$ test define the exchange rate has not a significant relation with the local oil price but fiscal policy effect and foreign oil price has a significant relation on the local oil price. Granger Causality test indicate that oil price volatility does not granger cause on public sector investment and gross domestic production does not granger cause on public sector investment is significant. Except these relationship, all other variables relationship exist and possible.

Findings. This research identify the effect of exchange rate, fiscal policy and international oil prices on oil prices of Pakistan. Different econometrics tests are utilized for analyses. Due to shortage of time, money and resources, this study only focus on Pakistan but this type of study can also implemented in Asia or more developing countries for more generalize effects and conclusion.

Originality. This is the first implemented research who define the magnitude, direction and effects among the variable in context of Pakistan. Before this research, there is only opinions are founds by different economists, politicians and analysists. 


\section{INTRODUCTION}

Crude oil is an important and most demanded commodity throughout the world. There are various processes like electricity production, manufacturing processes, transport sector and much more and in all these processes. Oil is the basic necessity thus is important to study the volatility in oil prices because oil price volatility reduces the aggregate output for short run and as a result uncertainty increases and investment also decreases (Guo and Kliesen, 2005).

It is now observed that demand of oil is also increasing like it was in developed countries. Especially Asian emerging economies has increased their demand and production of oil in recent past (Birol, 2007).It is important to note that the share of oil in the economy is very important. If the share is large then affect will be greater. It is also important to note the share of oil cots in national income. This will affect both exporting and importing countries according to the extent of their particular shares in the economy.

Other factors that play an important role are the dependence of consumers on oil and the degree to which they can find alternatives to switch to other resources due to increase price of oil in international market (IEA, 2006).

Oil is the major contributor in domestic economy and also constitutes to the gross domestic product of the state. According to the IEA, in 2000, oil constituted $4.0 \%$ to the globalenergy requirements. As the oil price will increase, it will also increase the production cost and transportation cost in many industries and household sector. It will also increase the inflation and wage rate will also rise high. Ultimately I will affect the economic growth (O'Neill, Penm\& Terrell, 2008).

The oil exporting countries are totally different from the other countries in many aspects as far as exchange rate and economic growth is concerned. The governments of oil exporting countries are large and powerful than small private secretor. The governments are strong because they receive the oil revenue which they earn from oil importing countries and hence structure of government and its policies play important role in the economic growth of the country. So in this regard the oil price is very important for oil exporting countries because the earn revenue to its maximum and use it for the economic growth of their country (Rosser \& Sheehan, 1995). The fiscal and monetary policies also depend on the oil prices and government uses these funds and revenues for its expenditure.

The changes are oil prices are highly uncertain and highly unpredictable. Sometimes the projects are stopped and companies wait for the oil price increase so they can start their projects again. Norway is an oil producing country and it first introduced such policies to make a stable economy for oil price fluctuations.

The other oil producers' such as Kuwait, Indonesia and many others followed these policies and preventive measures and somehow managed to adopt measures for oil price fluctuations (Devlin \& Lewin, 2004). 
The explanation for this is that until $197^{3}$, oil costs design in world was not unpredictable and around then it was hard to discover relationship between oil costs and stock costs and henceforth it is hard to comprehend the definite example keeping in mind the end goal to research the relationship between oil expenses and stock expenses and the components which influence these variables (Kilian, 2007; Driesprong et al., 2004).

Crude oil and stock market relationship was first studied by Jones and Kaul in 1996. These two proposed a model called "cash-flow dividend model" and explains the link in the middle of oil and securities exchanges. They focused on four significant economies United States, Japan, United Kingdom and Canada and they contemplated that these business sectors experience extraordinary effect of oil value stuns on the money streams. Along these lines it was inferred that present and future money streams can be impacted by value stuns.

These findings were mostly relevant to American and Canadian markets while Japanese and British market didn't show significant results of this study. After Generalized Autoregressive Conditional Hetero-skedasticity model was proposed in 1999 by Sadorsky, oil price volatility was understood. This model proposes that there is an immediate relationship between oil value instability and monetary movement and clarifies that adjustments in oil costs influence financial action.

As there is observed a decline in oil reserves, it is predicted that soon there will be oil shortage. This shortage of oil is alarming and is a factor of crude oil price changes. There is no exact prediction about how much oil reserves are left before the oil wells gets dried. After the OPEC states solidarity, the demand gets increased and price of oil also gets increased significantly in 2007-2008. These two factors were considered as the major forces of price movement in oil market.

There are some political factors that are responsible for the oil price changes worldwide. Some terrorist activities in oil producing and exporting countries are a considerable threat to the oil reserves and they are also responsible for oil price movement mainly an increase in oil prices. This results in an increase in oil prices worldwide because these countries are the largest exporters of oil worldwide.

\subsection{Exchange rate}

Exchange rate is a rate which is used for the conversion of one currency to another currency. Its vary from country to country and economy to economy specifically based on its economic condition.

Aliyu (2008) explains that conversion scale not just goes about as a between the residential business sector and the world business sector for products and resources, however it is likewise an intensity of a nation's trade power in global exchange. It additionally maintains the inner and outside macroeconomic equalizations over the medium-to-long haul. 
Mostly it is seen that researchers focus on the impact on exchange rate volatility rather than the source of exchange rate volatility. It is along these lines contended that comprehension the system of how those stuns influence the genuine swapping scale is imperative to execute a proficient and believable financial approach.

Sachs and Warner (2005) and Auty (2001) argued that looking at the growth rate of countries on the basis of natural resources; it was found that countries that have low natural resources will grow slower than those who have plenty of resources. Rickne (2009) explains that the exchange rates of resources are highly related to highly volatile commodity prices.

\subsection{Fiscal Policy}

Fiscal Policy is the means by which a government regulate its spending levels and tax rates to monitor and influence a nation's economy. It is the sister strategy to monetary policy through which a central bank influences a nation's money supply.

Many nations have reconsidered their fiscal and monetary policies between the borders and all these changes are caused due to globalization, scientific and technological changes. The world also experienced political and social changes and reforms and due to this financial system and economic life has totally changed. The accelerating and successive developments that world has seen Caused a number of changes (Amira et al., 2014).

In the context of the research, the price which is over to the international oil price and the effect of exchange rate on the oil price was taken as the fiscal policy effect. It is noted that no common policy was implemented by the government related to taxes and spending (subsidies) and volatility effect was implemented.

\section{LITERATURE REVIEW}

\subsection{Exchange rate and Oil}

The investigation of the impact of oil price shocks on the macroeconomic variables has extraordinarily mulled over through experimental examination. The market analysts and scrutinized concurred on the point that oil price shock diminishes monetary action and expands expansion rate in the meantime.

Ferraro et al. (2012) researches the degree to which oil costs have a dependable and stable linkage with the Canadian or U.S dollar ostensible exchange rate. The study discovered a bit deliberate relationship between oil costs and the exchange rate for the month to month and quarterly periods. There was very little effect found on daily basis. The linkage on daily basis was rather strong.

Buetzer et al. (2012) explores the degree to which oil stuns influence the worldwide currency exchange rate. The study was centered around genuine and ostensible 
trade rates and in addition on a trade business sector weight record for 44 progressed and developing nations. Utilizing VAR models, they discovered no proof that trade rates of oil exporters deliberately acknowledge against those of oil shippers consequential convulsions that raise the genuine oil cost. Then again, oil exporters experienced critical thankfulness weights taking after an oil interest stun, which they have a tendency to counter by aggregating remote trade holds.

Ansar and Asghar (2013) also explained the importance and effectiveness of oil in an economy. As Pakistan is an oil importing country so Pakistan pays foreign reserves to consumes oil. So oil price shocks will adversely affect the stock market and exchange rate of Pakistan.

Muhammad et al (2013) described the causes of inflation, gold price increase and foreign exchange rate and concluded that all these factors are affected by the oil price increase. All these factors also cause the high inflation and as a result the investment and economic activities get slowed down.

\subsection{Fiscal Policy, Oil and economic growth}

Katsuya Ito (2010) inspected the expansion rates in Russia from $1995^{\text {to }} 2009$ by utilizing the VAR model. The study was centered on discovering the levels of swelling. The study likewise discovers the effect of oil costs on the genuine powerful conversion scale and genuine GDP for Russia.

The result showed that the real GDP in long term will grow due to oil prices fluctuations. When there will be decrease in oil prices, it will stimulate inflation and it will also affect the economic growth. This will ultimately results in appreciation of real exchange rate.

Antonio and Ricardo (2011) additionally broke down the macroeconomic impacts of monetary strategy in Portugal from 1987 to 2007 by utilizing two models; a Bayesian Structural Auto relapse model (VAR) and a Simultaneous System approach. The Results demonstrated that broad government consumption stuns will adversely influence the genuine Gross Domestic Product (GDP) and it will brings about "swarming out" impacts.

These impacts comprise of private utilization and venture and they will emphatically influence the value level and government obligation. This model affirms that sudden positive spending stuns make significant "swarming out" impacts.

\subsection{Oil price and economic growth}

Oil volatility is the major and most critical constituent of world economy. In spite of the fact that there are numerous option assets to oil like wind, water, atomic and sunlight based power however the part of unrefined petroleum is still critical. Because of this focal significance, any adjustment in oil costs can affect both oil im- 
porting and oil sending out nations. Oil is of extraordinary significance for oil importing and in addition oil exporting economies.

Oil value changes have an immediate impact on monetary movement too concerning mechanical creation and GDP. It was found that if changes in oil costs influence the monetary action, it will influence the income of organizations for which oil is an info expense to generation. This shows the negative relationship between oil and output production.

Ji and Fan (2012) utilized bivariate EGARCH model with time differing connection development to study oil price instability overflow on other non-vitality items and found that the effect of raw petroleum market on other merchandise markets was more prominent when raw petroleum costs were high than when they were low.

Ahmad (2013) explained the industrial sector and the high demand of industrial sector to consume oil. When the oil price will increase, the production cost will also increase and as a result the overall production growth will slowed down. It was observed that industrial production decreased to a threatening level due to oil price increase.

Jawad (2013) studied different variables that cause the oil price volatility. He also analyzed the extent to which these variables affect the oil prices and as a result their impact on economic growth and economic development.

Monjazeb et al (2013) clarified the noteworthy effect of oil costs on financial development. Diverse variable used to figure the outcome. The Data of oil trading nations used to establish the consequence of oil price shock influence on financial development. The outcomes depicted that positive oil shock has positive effect and the other way around.

\subsection{Oil price volatility}

The most important factor contributing to oil price increase in the world is the unanticipated and high premium of risk associated with oil and its products and it is observed that this risk is increasing with time. Oil supply is also facing instability and imbalance in oil producing countries.

Oil price and income are the two main factors that set the demand side. As price increases, demand decreases and when income will be more, demand will ultimately increase. To the extent the supple side is concerned, the instabilities and concerns are more adaptable in light of the fact that is the capacity of stores, innovation, diminishment impact, slacks and leads and structure of the business sector (Robert Meier, Janet Roundtree and Michael Schaefer).

Basher and Sadorsky (2006) argued that when there will be rise in oil prices, it will leads to inflation tax. When there will be increase in oil prices, consumers will search for oil alternatives and they will look for other energy sources for the input of their industry. As other energy sources are not considered as best alternative as oil is 
and they can't substitute oil perfectly so there are many risks involved with this new substitute.

The most widely used structure for the oil market in determining the prices is the demand supply mechanism (Bacon, 1991; Dees et al., 2007). It is said that it is the most powerful mechanism that has great effect on the oil market and ultimately it determines the price of oil in oil market.

\section{DATAAND METHODOLOGY}

\subsection{Theoretical framework}

Renaissance growth theory/model was an off-shoot of the symmetric and asymmetry in effect schools. Lee (1998) who was a leading proponent of this school focused her theoretical work on attempting to distinguish between oil price changes and oil price volatility. Lee (1998) defined volatility as the standard deviation in a given period. She submitted that both have negative impacts on economic growth, but in different ways: Volatility has a negative and significant impact on economic growth immediately, while the impact of oil price changes delays until after a year. She concludes by stating that it is volatility/change in crude oil prices rather than oil price level that has a significant influence on economic growth.

The trade Economic theory proposed that oil volatility due to demand and supply shocks in the universal market have unusual effects or impacts on the non-oil trade balance and the oil trade balance of oil importers and exporters economies.

Renaissance growth theory/model was an off-shoot of the symmetric and asymmetry in effect schools. Lee (1998) who was a leading proponent of this school focused her theoretical work on attempting to distinguish between oil price changes and oil price volatility. Lee (1998) defined volatility as the standard deviation in a given period. She submitted that both have negative impacts on economic growth, but in different ways: Volatility has a negative and significant impact on economic growth immediately, while the impact of oil price changes delays until after a year. She concludes by stating that it is volatility/change in crude oil prices rather than oil price level that has a significant influence on economic growth.

My study topic is also related to oil price volatility, exchange rate, fiscal policy effect and economic growth of Pakistan and all above theories supports my research topic.

\subsection{Data}

Secondary data are collected from IEA, IFS and World Bank from 1973 to 2014 for estimation of coefficient. The data contain on yearly basis. 


\subsection{Tests for Stationarity}

Unit root test is used to define the trend, intercept and stationary of the secondary data for further usage. Unit root tests are performed on the log levels and first differentiations of our variables remembering the finished objective to investigate the universal properties of the data to define the game plan.

Consequently, three tests are used: Augmented Dickey-Fuller (Dickey and Fuller, 1981), Phillips Perron (Phillips and Perron, 1988) and Kwiatkowski, Phillips, Schmidt, Shin (Kwiatkowskietal, 1992) - with a consistent and design, and without example. The both ADF and PP tests is not valid stationarity a unit root, existing valid in each variable first difference, I(1) while the KPSS test is valid on $\mathrm{I}(\mathrm{O})$.

Unit root test is used to check the stationary of the data. The eight variables of time series data is stationary on the levels, at first difference and at second difference. The econometrics test Augmented Dickey-Fuller (ADF) unit root test is used for analysis of stationary The ADF test contains three type of situation for every time series. First, random selection process includes intercept (c) and trend (t). Second, random selection process includes intercept (c) but no trend (o). Third, random selection process includes lag length.

There is a trend in Oil price, Exchange rate and Selling oil price. Meanwhile, it is also anticipate a trend in Oil price volatility, Trade balance, Private sector investment, Public sector investment and Gross domestic production (GDP) of Pakistan.

Table1.: Augmented Dickey-Fuller test results

\begin{tabular}{|l|r|r|r|}
\hline \multicolumn{1}{|c|}{ Variables } & \multicolumn{1}{|c|}{$\begin{array}{c}\text { ADF test } \\
\text { statistics }\end{array}$} & Probability & \multicolumn{1}{|c|}{ Results } \\
\hline Oil price & -2.2500 & 0.4506 & $\mathrm{I}(\mathrm{o})$ \\
$\Delta$ Oil price & -9.1797 & 0.0000 & $\mathrm{I}(\mathrm{l})$ \\
Exchange rate & -3.3776 & 0.0685 & $\mathrm{I}(\mathrm{o})$ \\
$\Delta$ Exchange rate & -8.1095 & 0.0000 & $\mathrm{I}(\mathrm{l})$ \\
Selling oil price & -2.9245 & 0.1657 & $\mathrm{I}(\mathrm{o})$ \\
$\Delta$ Selling oil price & -7.0326 & 0.0000 & $\mathrm{I}(\mathrm{l})$ \\
Oil price volatility & -6.5313 & .00000 & $\mathrm{I}(\mathrm{o})$ \\
Trade balance & -2.4905 & 0.3310 & $\mathrm{I}(\mathrm{o})$ \\
$\Delta$ Trade balance & -7.5821 & 0.0000 & $\mathrm{I}(\mathrm{l})$ \\
Private sector investment & -2.314 .0 & 0.4173 & $\mathrm{I}(\mathrm{o})$ \\
$\Delta$ Private sector investment & -7.6049 & 0.0000 & $\mathrm{I}(\mathrm{l})$ \\
Public sector investment & -3.5224 & 0.0501 & $\mathrm{I}(\mathrm{o})$ \\
$\Delta$ Public sector investment & -6.2086 & 0.0000 & $\mathrm{I}(\mathrm{l})$ \\
GDP & 1.7332 & 0.9995 & $\mathrm{I}(\mathrm{o})$ \\
$\Delta$ GDP & -4.7057 & 0.0005 & $\mathrm{I}(\mathrm{l})$ \\
\hline
\end{tabular}

Source: Authors. 
The test result indicates that the variables Oil price, Exchange Rate, Selling Oil Price, Trade Balance, Private sector investment, Public sector investment and GDP have a unit root in their levels and are stationary in their first differences but variable Oil Price Volatility has stationary at level as Table 1 . demonstrate the results.

\section{4. $\operatorname{GARCH}(1,1)$ model}

To run the Generalized Autoregressive Conditional Heteroskedasticity $(\mathrm{GARCH}, 1,1)$ test it is compulsory to make all variable data stationary. So for that aspect, make Oil Price (purchasing price from the international market), Exchange Rate and Selling Oil Price stationary at ${ }_{1}{ }^{\text {st }}$ difference and represent Oil price as DOP, Exchange Rate as DER, Fiscal policy effect as DFY and Selling Oil Price as DSOP. After making these variable stationary, run the Generalized Autoregressive Conditional Heteroskedasticity (GARCHı, 1) on DER and DSOP. The following result revealed:

Estimation Equation of GARCH $(1,1)$ Model:

$\mathrm{DSOP}=\mathrm{C}(\mathbf{1}) * \mathrm{DER}+\mathrm{C}(\mathbf{2})$

GARCH = C(3) $+\mathrm{C}(4) * \operatorname{RESID}(-1) \wedge_{2}+\mathrm{C}(5) * \operatorname{GARCH}(-1)$

The estimation equation of $\operatorname{GARCH}(1,1)$ model described that dependent variable has auto-regress by its constant value which also include the GARCH value aspect and after that it is also auto-regress by its independent exchange rate.

Substituted Coefficients of GARCH $(1,1)$ Model:

DSOP $=-0.731936573393 * \mathrm{DER}+0.397331280819 * \mathrm{DOP}+$

0.0946797766996

GARCH $=0.0567521045296+0.0500268784889 * \operatorname{RESID}(-1)^{\wedge}{ }_{2}+$

$0.455602925823 * \mathrm{GARCH}(-1)$

DSOP $=-0.204801826082 * \mathrm{DER}+0.08634083907_{1} 3$

GARCH $=0.0527557654046-0.0159644565338 * \operatorname{RESID}(-1)^{\wedge} \wedge_{2}+$

$0.543480590538 * \mathrm{GARCH}(-1)$

The substituted coefficients describe that the coefficient of GARCH value is 0.0863 which impact as positive on selling oil price, meanwhile the exchange rate impact negatively on selling oil price and its coefficient value is - 0.204 .8 mean one unit increase in exchange rate decrease selling oil price by $0.204,8$ unit.

Table 2.: GARCH $(1,1)$

\begin{tabular}{|l|r|r|r|r|}
\hline & Coefficient & Std. error & \multicolumn{1}{c|}{ z-Statistic } & \multicolumn{1}{c|}{ Prob. } \\
\hline GARCH $(1,1)$ & 0.0863 & 0.1297 & 0.6659 & 0.5055 \\
DER & -0.2048 & 2.2617 & -0.0905 & $0.927^{8}$ \\
\hline
\end{tabular}

Source: Authors. 
According to GARCH $(1,1)$ table the impact of GARCH coefficient and exchange rate is not significant at even $10 \%$ of significance level. The $\mathrm{R}$ square value is 0.6023 which describe that the $60.23 \%$ selling oil price volatility is due to exchange rate and the remaining portion of oil price volatility is due to other factors and variables.

Consequently, afterward we run the Generalized Autoregressive Conditional Heteroskedasticity (GARCHı, 1) on DFY and DSOP. The following result discovered:

Estimation Equation of GARCH $(1,1)$ Model:

$\mathrm{DSOP}=\mathrm{C}(\mathbf{1})^{*} \mathrm{DFY}+\mathrm{C}(\mathbf{2})$

$$
\mathrm{GARCH}=\mathrm{C}(3)+\mathrm{C}(4) * \operatorname{RESID}(-1) \wedge_{2}+\mathrm{C}(5) * \operatorname{GARCH}(-1)
$$

The estimation equation of GARCH $(1,1)$ model described that dependent variable has auto-regress by its constant value which also include the GARCH value aspect and after that it is also auto-regress by its independent fiscal policy effect.

Substituted Coefficients of GARCH $(1,1)$ Model:

DSOP $=0.540787146143^{*} \mathrm{DFY}+0.0549894901047$

GARCH $=0.0312638126482+0.242156542289 * \operatorname{RESID}(-1)^{\wedge}{ }_{2}+$

0.0758828335797 *GARCH(-1)

The substituted coefficients describe that the coefficient of GARCH value is $0.055^{\circ}$ which impact as positive on selling oil price, meanwhile the fiscal policy effect impact positively on selling oil price and its coefficient value is $0.54,08$ mean one unit increase in fiscal policy effect increase selling oil price by $0.54,08$ unit.

Table 3.: GARCH $(1,1)$

\begin{tabular}{|l|r|r|r|r|}
\hline & \multicolumn{1}{|c|}{ Coefficient } & \multicolumn{1}{c|}{ Std. error } & \multicolumn{1}{c|}{ z-Statistic } & \multicolumn{1}{c|}{ Prob. } \\
\hline GARCH $(1,1)$ & $0.055^{\circ}$ & 0.0525 & 1.04 .68 & $0.295^{2}$ \\
DFY & 0.5408 & 0.0421 & 12.8304 & 0.0000 \\
\hline
\end{tabular}

Source: Authors.

According to GARCH $(1,1)$ table the impact of GARCH coefficient and fiscal policy effect is significant at even $1 \%$ of significance level. The R square value is 0.7808 which describe that the $78.08 \%$ selling oil price volatility is due to fiscal policy effect and the remaining portion of oil price volatility is due to other factors and variables.

Moreover, we run the Generalized Autoregressive Conditional Heteroskedasticity $\left(\mathrm{GARCH}_{1}, 1\right)$ on DOP and DSOP. The following result discovered:

Estimation Equation of GARCH $(1,1)$ Model:

$\mathrm{DSOP}=\mathrm{C}(\mathbf{1}) * \mathrm{DOP}+\mathrm{C}(\mathbf{2})$

$\mathrm{GARCH}=\mathrm{C}(3)+\mathrm{C}(4))^{*} \operatorname{RESID}(-1)^{\wedge} 2+\mathrm{C}(5) * \operatorname{GARCH}(-1)$

The estimation equation of GARCH $(1,1)$ model described that dependent variable has auto-regress by its constant value which also include the GARCH value as- 
pect and after that it is also auto-regress by its independent oil price.

Substituted Coefficients of GARCH $(1,1)$ Model:

DSOP $=0.3 \circ 867055^{828} \eta^{*} \mathrm{DOP}+0.0588 \circ 96968256$

$\operatorname{GARCH}=0.0578173197547+0.0246642490015^{*} \operatorname{RESID}(-1)^{\wedge}{ }_{2}+$

$0.47071417079 *$ GARCH(-1)

The substituted coefficients describe that the coefficient of GARCH value is $0.05^{88}$ which impact as positive on selling oil price, meanwhile the oil price (international) effect impact positively on selling oil price and its coefficient value is $0.3 \circ 87$ mean one unit increase in oil price (international) effect increase selling oil price by 0.3087 units. Table 4.: GARCH $(1,1)$

\begin{tabular}{|l|r|r|r|r|}
\hline & \multicolumn{1}{|c|}{ Coefficient } & \multicolumn{1}{c|}{ Std. error } & \multicolumn{1}{c|}{ z-Statistic } & \multicolumn{1}{c|}{ Prob. } \\
\hline GARCH $(1,1)$ & 0.0588 & 0.1066 & 0.5514 & $0.5^{814}$ \\
DOP & 0.3087 & 0.1760 & 1.7540 & 0.0794 \\
\hline
\end{tabular}

Source: Authors.

According to GARCH $(1,1)$ table the impact of GARCH coefficient and oil price is significant at $10 \%$ of significance level. The $\mathrm{R}$ square value is 0.6384 , which describe that the $63.84 \%$ selling oil price volatility is due to oil price and the remaining portion of oil price volatility is due to other factors and variables.

Moreover, we run the Generalized Autoregressive Conditional Heteroskedasticity (GARCHı, 1) on DER, DFY, DOP and DSOP. The following result observed:

Estimation Equation of GARCH $(1,1)$ Model:

$\mathrm{DSOP}=\mathrm{C}(1) * \mathrm{DER}+\mathrm{C}(2) * \mathrm{DFY}+\mathrm{C}(3) * \mathrm{DOP}+\mathrm{C}(4)$

GARCH $=\mathrm{C}(5)+\mathrm{C}(6) * \operatorname{RESID}(-1) \wedge_{2}+\mathrm{C}(\eta) * \operatorname{GARCH}(-1)$

The estimation equation of $\operatorname{GARCH}(1,1)$ model described that dependent variable has auto-regress by its constant value which also include the GARCH value aspect and after that it is also auto-regress by its independent exchange rate, fiscal policy and oil price (international).

Substituted Coefficients of GARCH $(1,1)$ Model:

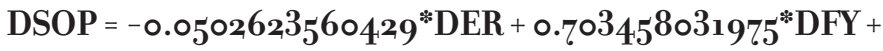

$0.34249143866^{*} \mathrm{DOP}+0.00242201942895$

GARCH $=-0.000313170210005+2.2490279077^{*} \operatorname{RESID}(-1)^{\wedge} 2+$

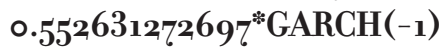

The substituted coefficients describe that the coefficient of GARCH value is $0.055^{\circ}$ which impact as positive on selling oil price, meanwhile the fiscal policy effect impact positively on selling oil price and its coefficient value is 0.5408 mean one unit increase in fiscal policy effect increase selling oil price by $0.54,08$ unit. 
Table 5.: GARCH $(1,1)$

\begin{tabular}{|l|r|r|r|r|}
\hline & \multicolumn{1}{|c|}{ Coefficient } & \multicolumn{1}{c|}{ Std. error } & \multicolumn{1}{c|}{ z-Statistic } & \multicolumn{1}{c|}{ Prob. } \\
\hline GARCH $(1,1)$ & 0.0024 & 0.0105 & 0.2297 & 0.8183 \\
DER & -0.0502 & 0.1220 & 97.2660 & 0.6805 \\
DFY & 0.7034 & 0.0072 & 29.6357 & 0.0000 \\
DOP & 0.3425 & 0.0115 & 0.2297 & 0.0000 \\
\hline
\end{tabular}

Source: Authors.

According to GARCH $(1,1)$ table the impact of GARCH coefficient and exchange rate is not significant at even $10 \%$ of significance level but fiscal policy effect and oil price (international) is significant at $10 \%$ level of significance. The $\mathrm{R}$ square value is 0.8491 which describe that the $84.91 \%$ selling oil price volatility is due to exchange rate, fiscal policy and oil price and the remaining portion of oil price volatility is due to other factors and variables.

\section{GRANGER CAUSALITY ANALYSIS}

Usually the VAR approach is used when we have an econometric hypothesis of interest that xt Granger causes Yt but Yt does not Granger cause . The Granger approach assesses whether past information on one variable would help in predicting the outcome of some other variable, given past information on the latter (Granger, 1969). It is important to note that, despite its name, Granger causality is not sufficient to imply true causality. Sims (1972) is a very famous paper showing that money Granger causes output, but output does not Granger cause money. Later Sims concluded that this does not hold if interest rates are included in the system. This illustrates a major drawback of the Granger causality test, namely the dependence on the right choice of the conditioning set, which, that we cannot assure, has been chosen large enough in practice. The Granger causality tests are most useful when the data are reasonably described by a 2-dimensional system. The tests may, however, produce misleading results when the true relationship involves three or more variables. Another potentially serious problem is the choice of sampling period: a long sampling period may hide the causality whereas for example VAR-systems of monthly data may give rise to serious measurement errors (e.g. due to seasonal adjustment procedures). Therefore, although Granger causality is a useful tool, it must be used and interpreted with care.

Granger Causality test is used to describe the casual relationship between the variables in the different econometrics models. The idea of Granger Causality is that a variable $X$ Granger causes variable $Y$ if variable $Y$ can be better predicted using the histories of both $\mathrm{X}$ and $\mathrm{Y}$ then it can be predicted using the history of $\mathrm{Y}$ alone. 
Table 6.: Granger Causality test result

\begin{tabular}{|c|r|r|r|}
\hline Null Hypothesis & Observations & \multicolumn{1}{c|}{ FStatistics } & \multicolumn{1}{c|}{ Probability } \\
\hline GDP does not Granger Cause OPV & 39 & 0.00821 & 0.9918 \\
OPV does not Granger Cause GDP & & 0.28185 & 0.7561 \\
\hline
\end{tabular}

Source: Authors.

The above table of Granger Causality test described that neither gross domestic production Granger cause the oil price volatility and nor the oil price volatility Granger cause the gross domestic production. Meanwhile, it is observed that both statements are not significant even 10\% level of significance, so it is concluded that the statement are not true or perfect or significant.

Table 7.: Granger Causality test result

\begin{tabular}{|c|r|r|r|}
\hline Null Hypothesis & Observations & F Statistics & \multicolumn{1}{c|}{ Probability } \\
\hline PRS does not Granger Cause OPV & 39 & 0.33896 & 0.7149 \\
OPV does not Granger Cause PRS & & 10.9927 & 0.0002 \\
\hline
\end{tabular}

Source: Authors.

The above table of Granger Causality test described that private sector investment does not Granger cause the oil price volatility and the statement is not significant even $10 \%$ level of significance. Meanwhile, the test define that oil price volatility does not Granger cause private sector investment and the statement is significant at $1 \%$ level of significance, so it is concluded that there is no causality relation between oil price volatility and private sector investment .

Table 8.: Granger Causality test result

\begin{tabular}{|c|r|r|r|}
\hline Null Hypothesis & Observations & \multicolumn{1}{c|}{ F Statistics } & \multicolumn{1}{c|}{ Probability } \\
\hline PS does not Granger Cause OPV & 39 & 0.71208 & $0.497^{8}$ \\
OPV does not Granger Cause PS & & $1.055^{86}$ & 0.3590 \\
\hline
\end{tabular}

Source: Authors.

The above table of Granger Causality test described that neither public sector investment Granger cause the oil price volatility and nor the oil price volatility Granger cause the public sector investment. Meanwhile, it is observed that both statements are not significant even $10 \%$ level of significance, so it is concluded that the statement are not true or perfect or significant. 
Table 9.: Granger Causality test result

\begin{tabular}{|c|r|r|r|}
\hline Null Hypothesis & Observations & \multicolumn{1}{c|}{ F Statistics } & \multicolumn{1}{c|}{ Probability } \\
\hline TB does not Granger Cause OPV & 39 & $\begin{array}{r}0.49987 \\
0.58196\end{array}$ & 0.6110 \\
OPV does not Granger Cause TB & & 0.5643 \\
\hline
\end{tabular}

Source: Authors.

The above table of Granger Causality test described that neither trade balance Granger cause the oil price volatility and nor the oil price volatility Granger cause the trade balance. Meanwhile, it is observed that both statements are not significant even $10 \%$ level of significance, so it is concluded that the statement are not true or perfect or significant.

Table 10.: Granger Causality test result

\begin{tabular}{|c|r|r|r|}
\hline Null Hypothesis & Observations & F Statistics & \multicolumn{1}{c|}{ Probability } \\
\hline PRS does not Granger Cause GDP & 39 & 1.13798 & 0.3324 \\
GDP does not Granger Cause PRS & & 0.16613 & 0.8476 \\
\hline
\end{tabular}

Source: Authors.

The above table of Granger Causality test described that neither private sector investment Granger cause the gross domestic production and nor the gross domestic production Granger cause the private sector investment. Meanwhile, it is observed that both statements are not significant even 10\% level of significance, so it is concluded that the statement are not true or perfect or significant.

Table 11.: Granger Gausality test result

\begin{tabular}{|c|r|r|r|}
\hline Null Hypothesis & Observations & \multicolumn{1}{c|}{ F Statistics } & \multicolumn{1}{c|}{ Probability } \\
\hline PS does not Granger Cause GDP & 39 & 1.80271 & 0.1803 \\
GDP does not Granger Cause PS & & 5.02844 & 0.0122 \\
\hline
\end{tabular}

Source: Authors.

The above table of Granger Causality test described that public sector investment does not Granger cause the gross domestic production and the statement is not significant even 10\% level of significance. Meanwhile, the test define that gross domestic production does not Granger cause public sector investment and the statement is significant at $5 \%$ level of significance, so it is concluded that there is no causality relation between gross domestic production and public sector investment . 
Table 12.: Granger Causality test result

\begin{tabular}{|c|r|r|r|}
\hline Null Hypothesis & Observations & \multicolumn{1}{c|}{ F Statistics } & \multicolumn{1}{c|}{ Probability } \\
\hline TB does not Granger Cause GDP & 39 & 0.224 .02 & 0.8005 \\
GDP does not Granger Cause TB & & $0.0545^{8}$ & $0.9477^{\circ}$ \\
\hline
\end{tabular}

Source: Authors.

The above table of Granger Causality test described that neither trade balance Granger cause the gross domestic production and nor the gross domestic production Granger cause the trade balance. Meanwhile, it is observed that both statements are not significant even 10\% level of significance, so it is concluded that the statement are not true or perfect or significant.

Table 13.: Granger Causality test result

\begin{tabular}{|c|r|r|r|}
\hline Null Hypothesis & Observations & F Statistics & \multicolumn{1}{c|}{ Probability } \\
\hline PS does not Granger Cause PRS & 39 & 1.96515 & 0.1557 \\
PRS does not Granger Cause PS & & 0.38791 & 0.6814 \\
\hline
\end{tabular}

Source: Authors.

The above table of Granger Causality test described that neither public sector investment Granger cause the private sector investment and nor the private sector investment Granger cause the public sector investment. Meanwhile, it is observed that both statements are not significant even 10\% level of significance, so it is concluded that the statement are not true or perfect or significant.

Table 14.: Granger Causality test result

\begin{tabular}{|c|r|r|r|}
\hline Null Hypothesis & Observations & \multicolumn{1}{c|}{ F Statistics } & \multicolumn{1}{c|}{ Probability } \\
\hline TB does not Granger Cause PRS & 39 & 0.16114 & $0.85^{18}$ \\
PRS does not Granger Cause TB & & 0.12671 & 0.8814 \\
\hline
\end{tabular}

Source: Authors.

The above table of Granger Causality test described that neither trade balance Granger cause the private sector investment and nor the private sector investment Granger cause the trade balance. Meanwhile, it is observed that both statements are not significant even 10\% level of significance, so it is concluded that the statement are not true or perfect or significant.

Table 15.: Granger Causality test result

\begin{tabular}{|l|r|r|r|}
\hline \multicolumn{1}{|c|}{ Null Hypothesis } & Observations & \multicolumn{1}{c|}{ F Statistics } & \multicolumn{1}{c|}{ Probability } \\
\hline TB does not Granger Cause PS & 39 & 1.63092 & 0.2107 \\
PS does not Granger Cause TB & & 1.27067 & 0.2936 \\
\hline
\end{tabular}

Source: Authors. 
The above table of Granger Causality test described that neither trade balance Granger cause the public sector investment and nor the public sector investment Granger cause the trade balance. Meanwhile, it is observed that both statements are not significant even 10\% level of significance, so it is concluded that the statement are not true or perfect or significant.

\section{CONCLUSION}

The results and outcomes based on the time series data of oil price (international oil price), exchange rate of Pakistan, selling oil price in Pakistan (which have international oil price, exchange rate effect and fiscal effect of the local government is including), oil price volatility, trade balance, private sector investment, public sector investment and gross domestic production of Pakistan from 1973 to 2014.

It is observed that the time series data of variables (Oil price, exchange rate, selling oil price, Trade balance, Public sector investment, private sector investment and Gross Domestic production of Pakistan) have a trend and also not stationary at level. After using unit root test (ADF) it is found that all variables are stationary at first difference. Oil price volatility has a trend but the variable is stationary at level.

It is anticipated through Generalized Autoregressive Conditional Heteroskedasticity $(\mathrm{GARCH}, 1)$ that exchange rate of Pakistan has an insignificant effect on the oil price in Pakistan even at the 10\% level of significance. Meanwhile, fiscal effect in oil price in Pakistan and oil price (international market price) has significant impact on oil price of Pakistan at the $1 \%$ and $10 \%$ level of significance respectively which is also same as the theoretical frame work described. After the analysis it is prescribed that $\mathrm{H}_{1 \mathrm{~N}}$ hypothesis rejected that exchange rate effecting the oil prices, $\mathrm{H}_{2 \mathrm{~N}}$ Hypothesis accepted Fiscal policy effecting the oil prices and $\mathrm{H}_{3 \mathrm{~N}}$ Hypothesis accepted that oil price (international) effecting the oil prices (local). Pakistan is a developing economy and the variation of fiscal policy and international oil prices may more effect on the price substitution then the exchange rate effect.

Subsequently, Granger Causality test is used to describe the casual relationship between the variables (oil price volatility, trade balance, private sector investment, public sector investment and gross domestic production). The test indicate that oil price volatility does not granger cause on public sector investment and gross domestic production does not granger cause on public sector investment is significant. Except these relationship, all other variables relationship exist and possible.

\section{RECOMMENDATION}

The directly impact of elevated oil prices (purchased from the foreign countries) on the economies (in the emerging economies) is anticipated through the deterioration of balance of payments, exchange rate and consequential contraction of 
the economies. So that's why there is a requirement to explore the oil alternatives that steadily decrease the impact of the oil price volatility and will make potential of the economy more stronger to face volatility crisis.

Government should make a proper plan and procedure according to economic growth and requirement which would help to maintain the equilibrium and decrease the effect of oil price volatility. Meanwhile, government should decrease its fiscal effect which is the major source of its income but at the same time major effect to increase the oil prices. Government of Pakistan should develop a proper formula to decrease the effect of oil price volatility to increase its economic growth. 


\section{REFERENCE}

Aliyu, S.U.R. (2008). Exchange Rate Volatility and Export Trade in Nigeria:An Empirical Investigation.

Amira Driss, Samir Bettahar\& Mohamed Benbouziane (2014). Fiscal Policy Shocks and Real Exchange Rate Dynamics:-An Empirical Investigation in the case of Algeria, International Journal of Arts and Commerce, Vol. 3 No. 1.

Ansar, Ibraheem. andAsghar, Nadia. The Impact of Oil prices on stock exchange and CPI in Pakistan, IOSR journal of Business and Management, Vol. 7, No. 6, (2013): 32-36

Antonio Afonso, Ricardo M.Sousa. The Macroeconomic Effects Of Fiscal Policy, The Economic Journal, (2009): $\mathrm{F}_{4}-\mathrm{F} 32$

Auty, R. (2001). Resource Abundance and Economic Development, Oxford, Oxford University Press.

Basher, S.A. and Sadorsky, P. Oil price risk and emerging stock markets, Golobal Finance Journal, Vol 17, (2006): 224-251

Buetzer S, Habib MM, and Stracca, L. (2012). Global Exchange Rate Configurations. Do Oil Shocks Matter?, Working Paper Series No. 1442.

Dees, S., Karadeloglou, P., Kaufmann, R.K., Sanchez, M. Modelling the world oil market: Assessment of quarterly econometric model, Energy Policy, Vol35, (2007): 178-191

Devlin, J., Lewin, M. (2004). Managing Oil Booms and Busts in Developing Countries, Draft Chapter for Managing Volatility and Crises, A Practitioner's Guide.

Driesprong, G., Jacobsen, B. and Maat, B. (2004). Stock markets and oil prices, Working Paper, Rotterdam School of Management, Erasmus University Rotterdam.

Ferraro D, Rogoff K, Rossi. (2012). Can Oil Prices Forecast Exchange Rates?, Duke University Harvard University ICREA-UPF, BGSE, CREI.

Guo, H and Kliesen, K. (2005). Oil price Volatility and U.S. Macroeconomic Activity, Federal Reserve Bank of St.Louis Review.

Jawad, Muhammad.An econometrics Analysis of Oil price volatility, International journal of economics and finance management, Vol. 1, No. 1, (2013): 1-4

Katsuya Ito. The impact of oil price volatility on the macro economy in Russia, Springer-Verlag, Economic Analysis Working Papers, Vol 9(5), (2010): 1-8

Kilian, L. Not All Price Shocks Are Alike: Disentangling Demand and Supply Shocks in the Crude Oil Market, American Economic Review, Vol 99, (2007): 1053-1069

Monjazeb, Mohmmadreza.,Souri, Ali.andShahabi, Zahra. The effect of oil price shocks on economic growth (case study selected oil exporting countries), Technical journal of engineering and applied sciences, Vol. 3, No. 17, (2013): 2118-2122.

Muhammad, Bin. Khalid.,Hussain, Khalid.and Hassan, Farrukh. (2013). Effect of International Gold price, Oil price and Foreign Exchange Rate on Inflation in Pakistan. International journal of management research and business strategy, Vol. 2, No.2.

O'Neill, Penm\& Terrell. (2008). The role of higher oil prices: A case of major developed countries, Research in Finance, Emerald Group Publishing Limited.

Phillips, P.C.B. and Perron, P. Testing for a unit root in time series regression, Biometrika, Vol 75 (2), (1988): $335-34,6$ 
Rickne, J. (2009). OilPrices and Real Exchange Rate Movements in OilExporting Countries: The Role of Institutions, Research Institute of Industrial Economics, IFN Working Paper No. 81o. (http://www.ifn.se/ Wfiles/wp/wp810.pdf)

Rosser, J. B., Sheehan, G. R.A Vector AutoRegressive Model for Saudi Arabian Economy, Journal of Economics and Business, $\operatorname{Vol}_{47}(1),(1995): 79^{-90}$

Sachs J, Warner M. Natural Resource Abundance and Economic Growth, In: G.M. Meier, J.E. Rauch (Eds.), Leading Issues in Economic Development, eighth ed. Oxford University Press, New York (2005): 161-168

Sims, C.A.. Money, Income and Causality, American Economic Review, Vol 62 (4), (1972): 540-542 